\title{
Controlled-Release Fertilizer and Container Volume to Produce Inga laurina Seedlings
}

\author{
Gerhard Valkinir Cabreira ${ }^{1}$ \\ Paulo Sérgio dos Santos Leles ${ }^{1}$ \\ Jorge Makhlouta Alonso ${ }^{1}$ (C) \\ Alexander Silva de Resende ${ }^{2}$ (1) \\ Wilbert Valkinir Cabreira ${ }^{1}$ (1) \\ Thasso José Silva e Sousa ${ }^{1}$
}

\begin{abstract}
This study evaluated the production of Inga laurina (Sw.) Willd seedlings in 110 and $280 \mathrm{~cm}^{3}$ tube containers and growing doses $\left(0,3,6\right.$ and $\left.12 \mathrm{~kg} \mathrm{~m}^{-3}\right)$ of controlled-release fertilizer (CRF) (15-09-12) and their performance at 5 and 12 months after outplanting. The experiment was conducted using a randomized split-plot design, in a $2 \mathrm{x} 4$ arrangement (tube volumes $\mathrm{x}$ CRF doses). Stabilized sewage sludge from urban origin was used as substrate. It was assessed growth and biomass of the seedlings in nursery, as well as survival and growth after outplanting. Containers of $280 \mathrm{~cm}^{3}$ and doses between 6 to $12 \mathrm{~kg} \mathrm{~m}^{-3}$ produced seedlings in less time, with higher growth and biomass. At 12 months after outplanting, seedlings presented acceptable growth and mortality rate with doses equal or greater than 6 and $3 \mathrm{~kg} \mathrm{~m}^{-3}$ of CRF, respectively, for the 110 and $280 \mathrm{~cm}^{3}$ tube.
\end{abstract}

Keywords: Sewage sludge, plastic tube, forest nursery.

\section{INTRODUCTION AND OBJECTIVES}

The most usual technique for restoration of the Atlantic Forest is the planting of seedlings from native species. The Inga spp. gender are among the most widely adopted in forest restoration, especially due to its high phenotypic plasticity (Martins at al., 2015). The species Inga laurina (Sw.) Willd has a wide phytogeographic distribution and an ecological importance, considering its fruits are a source of food for wild animals (Souza \& Lorenzi, 2005).

Among the factors that influence in forest seedlings quality, type and volume of the containers have a fundamental role in provide a proper growth of roots, contain the substrate, control the water stress and protect the roots from physical damage (Gasparin et al., 2014; Ferraz \& Engel, 2011). Polypropylene tubes are between the most used containers to produce forest seedlings, they can have different shapes and sizes and present the advantages of being reusable, light and easy to handle, their use can improve ergonomics during nursery activities and allow the mechanization of some operations (Freitas et al., 2006).

Fertilization is another factor that influences the final quality of seedlings. The controlled-release fertilizer (CRF) technology is designed to enable a better rate of nutrient uptake, considering the dynamics of need during the plants growth (Irfan et al., 2018). The use of CRF can reduce production costs, because of a shorter crop cycle, less operations, as well as the optimization of space, water and energy use (Gibson et al., 2019).

In average, seedlings of Atlantic Forest species are ready for outplanting after four to six months in the nursery. Considering the small volume of substrate in the plastic tubes, seedlings may struggle with nutritional deficiency during the production period, which can be aggravated by the recurrent irrigations, leading to eventual nutrients leaching. Thus, even when adopting a substrate that is rich in nutrients, the necessity of mineral fertilization should be considered.

This study evaluated the effect of four doses $(0,3,6$ and $12 \mathrm{~kg} \mathrm{~m}^{-3}$ ) of controlled-release fertilizer (15-09-12) and two

${ }^{1}$ Universidade Federal Rural do Rio de Janeiro (UFRRJ), Seropédica, RJ, Brasil

${ }^{2}$ Empresa Brasileira de Pesquisa Agropecuaria (EMBRAPA), Centro Nacional de Pesquisa em Agrobiologia, Seropédica, RJ, Brasil 
plastic tubes (110 and $280 \mathrm{~cm}^{3}$ ) to produce Inga laurina (Sw.) Willd (ingá) seedlings. The survival and initial growth of the seedlings after outplanting was also evaluated.

\section{MATERIALS AND METHODS}

\subsection{Nursery phase}

The experiment was conducted from June to November 2015 in a nursery located in the geographical coordinates $22^{\circ} 45^{\prime} 27^{\prime \prime} \mathrm{S}$ and $43^{\circ} 41^{\prime} 45^{\prime \prime} \mathrm{W}$. The species evaluated was Inga laurina (Sw.) Willd, known locally as "ingá". According to Köppen-Geiger classification, the climate of the region is Aw (tropical with dry winter and rainy summer). Considering data of the last 20 years from the Empresa de Pesquisa Agropecuária do Estado do Rio de Janeiro (PESAGRO-RJ) weather station, the means are: annual rainfall $1.245 \mathrm{~mm}$; relative air humidity $69 \%$; temperature $23,7^{\circ} \mathrm{C}$; temperature of the hottest month (February) $27,0^{\circ} \mathrm{C}$; and of coldest month (July) $20,6^{\circ} \mathrm{C}$.

This experiment was conducted using a randomized split-plot design, in a $2 \times 4$ arrangement, with two distinct plastic tubes $\left(110\right.$ and $280 \mathrm{~cm}^{3}$ ) as whole plots, and four CRF doses $\left(0,3,6\right.$ and $\left.12 \mathrm{~kg} \mathrm{~m}^{-3}\right)$ as subplots, on a total of eight treatments with five replications each. In the $110 \mathrm{~cm}^{3}$ tube, each replication consisted of ten seedlings and for $280 \mathrm{~cm}^{3}$ there were six seedlings per replication.

The substrate consisted of $100 \%$ sewage sludge, provided by Companhia Estadual de Águas e Esgoto do Rio de Janeiro (CEDAE). The sludge came from the wastewater treatment plant (WWTP) of Ilha do Governador, Rio de Janeiro - RJ. This WWTP receives sewage from urban areas, treating it at secondary level, using the activated sludge process. The sludge generated during the treatment is thickened in centrifuge, then dried and stabilized in open air semipermeable beds, where it stays for approximately 90 days, until it reaches at least $30 \%$ of humidity. Before the incorporation of CRF, a sample of the sewage sludge was taken for chemical and density analyzes (Table 1).

The fertilizer doses were $0,3,6$ and $12 \mathrm{~kg}$ of CRF (N-P-K 15-09-12) per $\mathrm{m}^{3}$ of substrate, the control treatment was the one without fertilization. This product is coated by a water permeable organic resin that releases $15 \% \mathrm{~N}, 9 \% \mathrm{P}_{2} \mathrm{O}_{5}$ and
$12 \% \mathrm{~K}_{2} \mathrm{O}$, besides of $1 \% \mathrm{Mg}, 2.3 \% \mathrm{~S}, 0.05 \% \mathrm{Cu}, 0.45 \% \mathrm{Fe}$ and $0.06 \% \mathrm{Mn}$, in 8 to 9 month period, according to the fertilizer manufacturer.

The seeds of Inga laurina were collected from at least 10 different trees located in Seropédica - RJ. The fruits were taken to the nursery, where they were peeled, and the seeds aryl was removed. There was no treatment for breaking seeds dormancy and the sowing was done right after processing, in plastic trays filled with sand. The saplings were transplanted to the tubes when they had at least two pairs of true leaves.

After transplanting, tubes trays were placed under shade house with $50 \%$ of light block for 15 days, then they were taken to open air beds until the end of the experiment. At 72 days after transplanting the seedlings were rearranged to $50 \%$ of tray occupation (one seedling per each two cells), to reduce competition. Seedlings were irrigated twice a day by micro-sprinklers, in the early morning and late afternoon, with a depth of approximately $4 \mathrm{~mm}$ per irrigation. Weeding was conducted whenever the need was observed.

At 30 days after transplanting, the shoot height was measured with a graduated ruler, this operation was repeated in 42-day intervals until 156 days after transplanting, when seedlings were considered ready to be planted. At 156 days after transplanting, the stem diameter was also measured, using a digital caliper. Five seedlings per treatment were selected to determine leaf area (LA), shoot (SDM) and root dry matter (RDM). LA was evaluated with the specific device LICOR-3600. Shoots and roots were oven-dried at $65^{\circ} \mathrm{C}$ for 72 hours and then weighted to determine SDM and RDM. Data on growth and biomass of the seedlings were used to calculate the Dickson's quality index (DQI).

Once dry matter was weighted, shoot samples were processed in a knife mill for the analysis of macronutrients contents in seedlings tissues. Each sample was identified and sent to the analysis of $\mathrm{P}, \mathrm{K}, \mathrm{Ca}$ and $\mathrm{Mg}$ total contents, by optical emission spectrometry (ICP-OES), after nitric-perchloric acid digestion. The total content of $\mathrm{N}$ was determined in $\mathrm{CHNS}$ elemental analyzer.

To estimate the ideal dose of fertilizer in each container the maximum technical efficiency dose (MTED) was calculated through linear regression equations, considering height, diameter, LA and SDM in the different CRF doses.

Table 1. Chemical analysis of the sewage sludge used as substrate to produce Inga laurina seedlings.

\begin{tabular}{|c|c|c|c|c|c|c|c|c|}
\hline${ }^{{ }^{*}} \mathbf{p H}$ & ${ }^{{ }^{*} 2} \mathbf{N}$ & ${ }^{{ }^{*}} \mathbf{P}$ & ${ }^{*} \mathbf{K}^{+}$ & ${ }^{{ }^{5}} \mathrm{Ca}$ & ${ }^{{ }^{*}} \mathrm{Mg}$ & ${ }^{{ }^{* 5}} \mathrm{Al}$ & ${ }^{{ }^{*}}$ O.M. & Density \\
\hline & & & & $\%$ & & & & $\mathrm{~kg} \mathrm{dm}^{-3}$ \\
\hline 5.5 & 1.94 & 0.81 & 0.19 & 1.59 & 0.19 & 2.72 & 35.3 & 0.72 \\
\hline
\end{tabular}

${ }^{{ }^{1} \mathrm{pH}}$ in water: Potentiometry; ${ }^{{ }^{2} \mathrm{~N}}$ : Kjeldahl; ${ }^{{ }^{3} \mathrm{P}}$ : Colorimetric analysis; ${ }^{{ }^{4} \mathrm{~K}}$ : Flame Photometry; ${ }^{{ }^{5} \mathrm{Ca}}$, Mg e Al: Atomic Absorption Spectometry; ${ }^{{ }^{6} \mathrm{O} . \mathrm{M}}$. (Organic Matter): Gravimetric analysis 


\subsection{Outplanting phase}

The outplanting was done on December 3, 2015, four days after the last nursery evaluation, at the Estação Ecológica de Guaxindiba, in São Francisco do Itabapoana - RJ. The experiment was conducted from December 2015 to December 2016. The site was historically occupied by sugarcane plantation, had a plain topography, average altitude of 25 meters above sea level and the soil was classified as RedYellow Argisol, by the Brazilian Soil Taxonomy System, with sand clay texture, containing $60 \%$ sand, $38 \%$ clay and $2 \%$ silt. The region climate was classified as Cwa type (subtropical with dry winter and hot summer) by KöppenGeiger classification.

The average of the monthly water balance was calculated with data from January 1996 to November 2016, registered by the meteorological station of Campos dos Goytacazes - RJ. Results showed water deficit during the whole year, with exception of November and December, and more intensified from June to August. Precipitation data, collected in the experimental area pluviometer, from December 1, 2015 to November 30, 2016, showed accumulated rainfall of $891 \mathrm{~mm}$. In the first five months after outplanting - December, January, February, March and April - precipitation summed 137.5; 285.7; 131.7; 101.5 and $49.9 \mathrm{~mm}$, respectively, with $10,18,6,8$ and 5 rainy days in each month.

Planting was done in $3 \times 2 \mathrm{~m}$ spacing, with planting pits of $50 \times 50 \mathrm{~cm}$ (width and depth). Due to the homogeneity of the experimental area, the seedlings were planted in a completely randomized design, considering each seedling as one replication. The treatments were the same evaluated in the nursery, for each of them, twenty seedlings were planted. The seedlings were allocated in twenty rows, intercalating one Inga laurina seedling, with three of other species. On every row, there was one seedling of each treatment.

After planting, seedlings were manually irrigated with approximately four liters of hydrated hydrogel (dilution of $1 \mathrm{~g}$ of hydrogel per $1 \mathrm{~L}$ of water). To avoid interference in the results of the nursery treatments, no fertilization was done during the planting. There were evaluated the seedlings survival, the height $(\mathrm{H})$ and the diameter at $5 \mathrm{~cm}$ above ground level (DGL) at 12 months after planting.

\subsection{Statistical analysis}

The data was tested for homogeneity of variance and normality of residuals through Barlett and Lilliefors tests at 5\% significance level.
In the nursery phase, all measured variables were submitted to analysis of variance, when significance was detected between plastic tubes the t-test was performed, considering $5 \%$ significance level. In the case of significance observed between CRF doses, data were submitted to regression analysis and verified by Graybill model identity test. The same test was performed to evaluate shoot height over time.

Regarding the planted seedlings, data of height and DGL were submitted to analysis of variance, when significance was observed, treatments were compared with the t-test between the different containers.

\section{RESULTS AND DISCUSSION}

\subsection{Nursery phase}

The seedlings presented linear growth through time in both containers (Figure 1) with significant difference between the equations along the experimental period. We observed identical statistical models in Figure 1 for both containers, in the CRF doses of 6 and $12 \mathrm{~kg} \mathrm{~m}^{-3}$, reaching superior average height than in 0 and $3 \mathrm{~kg} \mathrm{~m}^{-3}$ doses. Seedlings that have not received fertilization showed the lowest average height in both containers, demonstrating the potential of Inga laurina seedlings to respond the mineral fertilization, what is being observed for native Atlantic Forest species from different successional stages (Moraes Neto et al., 2003).

All treatments demonstrated linear growth in height until the last assessment, suggesting that seedlings would continue to grow if kept in the nursery. Seedlings in $110 \mathrm{~cm}^{3}$ tubes, independent of the CRF dose, and in $280 \mathrm{~cm}^{3}$ control treatment require a longer growth phase.

Considering the shoot height, seedlings cultivated in the larger container $\left(280 \mathrm{~cm}^{3}\right)$ with CRF doses of 6 and $12 \mathrm{~kg} \mathrm{~m}^{-3}$ were suitable to outplanting at 132 days after transplanting, 24 days prior than expected. This result shows that using sewage sludge as substrate, together with chemical fertilizing, can accelerate forest seedlings growth. A similar pattern was observed for Inga laurina by Jesus et al. (2016), where seedlings produced in $115 \mathrm{~cm}^{3}$ tubes showed similar growth in height and diameter for a production period of 81 days (after transplanting) with fertilization and of 110 days without fertilization. The shortest time to produce suitable seedlings implies in lower production costs, considering the savings with irrigation and labor force for seedling care (Bamberg et al., 2013). Nevertheless, it is necessary further evaluation to consider whether this retraction compensates the additional costs of using CRF instead of a cheaper fertilizer. 

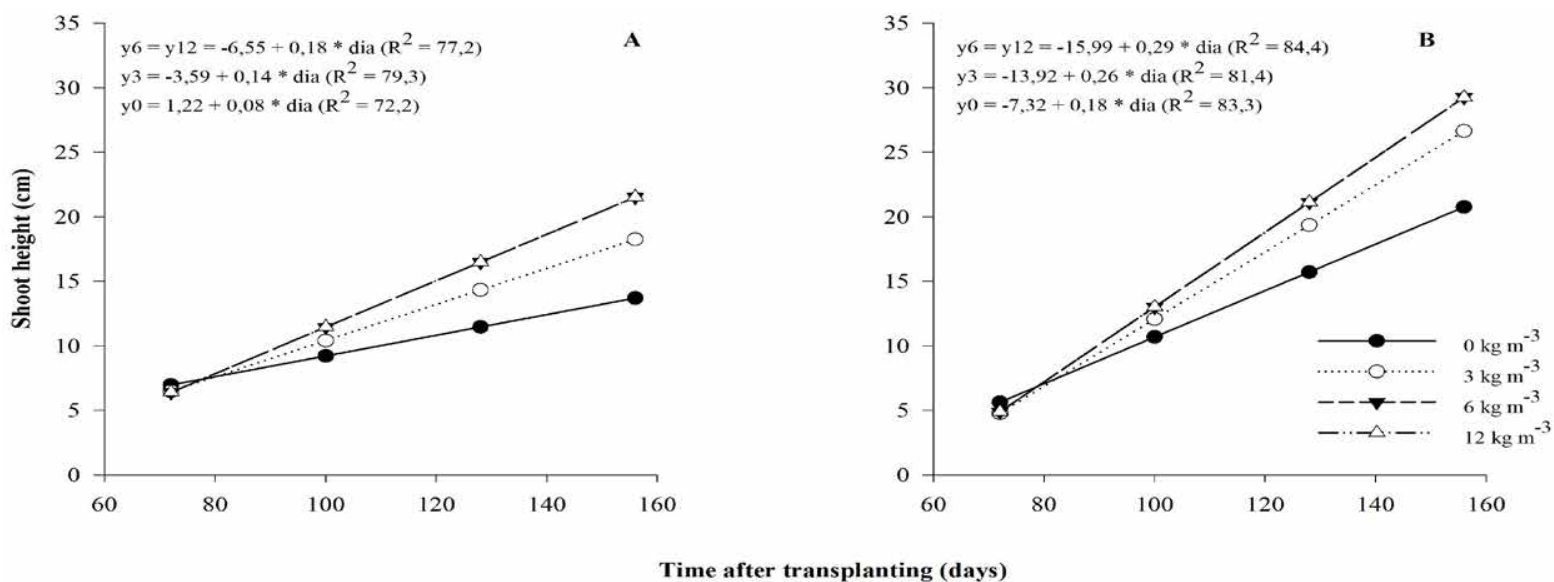

Figure 1. Average shoot height of Inga laurina seedlings in plastic tubes of $110 \mathrm{~cm}^{3}$ (A) and $280 \mathrm{~cm}^{3}$ (B) and with increasing doses of CRF during 156 days of production in the nursery. "significant at $5 \%$ level according to model identity test.

There was no interaction between container volume and CRF doses. For isolated factors it was verified significant differences between containers and doses. Similar result was reported by Pias et al. (2015) in evaluation of Cedrela fissilis seedlings produced with different fertilizers and containers, the authors did not found interaction between these factors, but observed significant difference between treatments in the isolated analysis. In contrast, Stüpp et al. (2015) have found significant interaction between container size (110 and $\left.180 \mathrm{~cm}^{3}\right)$ and CRF doses (0, 3,6 and $9 \mathrm{~kg} \mathrm{~m}^{-3}$ ) for Mimosa scabrella seedlings, pointing out that such interaction can depend on substrate, environment conditions, species, amongst other factors.

In all fertilizer doses and for all growth variables, except for the RDM in $3 \mathrm{~kg} \mathrm{~m}^{-3}$ dose, seedlings produced in the 280 $\mathrm{cm}^{3}$ tube were superior to those in the $110 \mathrm{~cm}^{3}$ (Table 2). This pattern, according to Leles et al. (2006) and Melo et al. (2018) is associated to the volume of substrate, since larger containers provides greater space for roots to grow, as well as a higher amount of water and nutrients retained in the substrate.
The higher growth of Atlantic Forest seedlings in larger tubes have also been observed by Ferraz \& Engel (2011) for Hymenaea courbaril, Tabebuia chrysotricha e Parapiptadenia rígida, comparing 50,110 and $300 \mathrm{~cm}^{3}$ containers, by Stüpp et al. (2015) assessing Mimosa scabrella in 110 and $280 \mathrm{~cm}^{3}$ tubes, among other authors. However, as reported by Ferraz \& Engel (2011), growth gains observed in larger containers must compensate the higher expenses with substrate, shipping and logistics, lower efficiency in outplanting operations and greater space occupied by seedlings in the nursery.

In general terms, controlled-release fertilizer (CRF) has accelerated the seedlings growth (Figure 2), even considering that the sewage sludge was a substrate rich in nutrients (Table 1). Similar results were verified by Scheer et al. (2012a; 2012b), on experiments with Prunus brasiliensis and Anadenanthera colubrina, both species showed adequate growth when cultivated without fertilization in composted sewage sludge. However, better results were observed when CRF was applied, being recommended the dose of $2.7 \mathrm{~kg} \mathrm{~m}^{-3}$ for the $110 \mathrm{~cm}^{3}$ tube.

Table 2. Average values of morphological parameters for Inga laurina seedlings, at 156 days after transplanting, produced in two plastic tubes $\left(110\right.$ and $\left.280 \mathrm{~cm}^{3}\right)$ and four CRF doses $\left(0,3,6\right.$ and $\left.12 \mathrm{~kg} \mathrm{~m}^{3}\right)$.

\begin{tabular}{|c|c|c|c|c|c|c|c|c|c|c|}
\hline \multirow{2}{*}{$\begin{array}{l}\text { CRF Doses } \\
\left(\mathrm{kg} \mathrm{m}^{-3}\right)\end{array}$} & \multicolumn{2}{|c|}{ Height $(\mathrm{cm})$} & \multicolumn{2}{|c|}{$\mathrm{SD}(\mathrm{mm})$} & \multicolumn{2}{|c|}{$\mathrm{LA}\left(\mathrm{cm}^{2}\right)$} & \multicolumn{2}{|c|}{ SDM (g) } & \multicolumn{2}{|c|}{ RDM (g) } \\
\hline & 110 & 280 & 110 & 280 & 110 & 280 & 110 & 280 & 110 & 280 \\
\hline 0 & 13.2 & $20.9^{*}$ & 3.3 & $4.3^{*}$ & 48 & $168^{\star}$ & 5.6 & $7.2^{\star}$ & 5.2 & $5.8^{\star}$ \\
\hline 3 & 18.5 & $27.0^{*}$ & 4.4 & $5.5^{\star}$ & 110 & $242^{\star}$ & 6.8 & $8.6^{*}$ & 6.2 & $6.8^{\mathrm{ns}}$ \\
\hline 6 & 21.0 & $30.1^{\star}$ & 5.2 & $6.1^{\star}$ & 163 & $280^{*}$ & 7.5 & $9.9^{*}$ & 6.3 & $7.4^{\star}$ \\
\hline 12 & 22.8 & $29.5^{*}$ & 5.5 & $6.1^{\star}$ & 148 & $313^{*}$ & 8.0 & $10.5^{\star}$ & 6.5 & $8.1^{\star}$ \\
\hline
\end{tabular}

SD - stem diameter; LA - leaf area; SDM - shoot dry matter; RDM - root dry matter. * values for the same parameter and between different tube volumes are significative at $5 \%$ level, according to t-test. ${ }^{\text {ns }}$ not significative. 

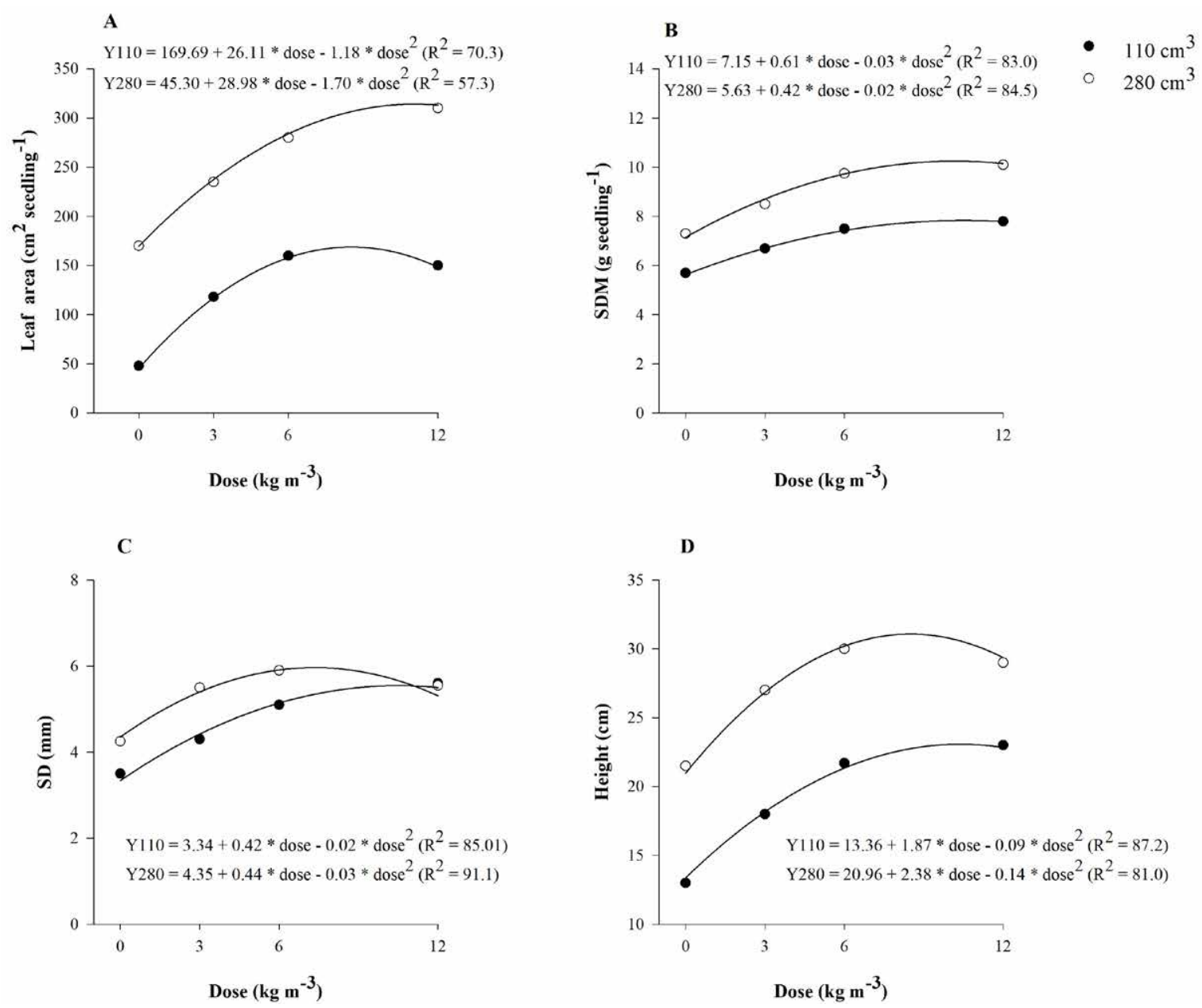

Figure 2. Regression equations for leaf area, shoot dry mass (SDM), stem diameter (SD) and shoot height of Inga laurina seedlings produced in two plastic tubes $\left(110\right.$ and $\left.280 \mathrm{~cm}^{3}\right)$ and four CRF doses $\left(0,3,6\right.$ and $\left.12 \mathrm{~kg} \mathrm{~m}^{3}\right)$ at 156 days after transplanting. ${ }^{*}$ significant at $5 \%$ level according to model identity test.

Seedlings produced in 110 and $280 \mathrm{~cm}^{3}$ containers demonstrated quadratic growth behavior for height, diameter, leaf area and SDM, in function of the CRF doses (Figure 2). Similar results were observed in other studies with Atlantic Forest seedlings submitted to increasing doses of CRF (Gibson et al., 2019; Gasparin et al., 2015), which also noted that from a given dose there is no increase in growth and/or biomass and there may even be harmful effects. According to Rossa et al. (2013) this behavior shows that plants have a maximum biologic growth at an ideal dose, which is identified as maximum technical efficiency dose (MTDE), estimated through the derivative of the equation adjusted for a given growth variable.

In the present study, the MTED was higher in the $110 \mathrm{~cm}^{3}$ containers for all evaluated parameters, except leaf area, with an average value of $10 \mathrm{~kg} \mathrm{~m}^{-3}$ (Table 3). For the larger tube $\left(280 \mathrm{~cm}^{3}\right)$ the average MTDE was $9.2 \mathrm{~kg} \mathrm{~m}^{-3}$, as this container needs lower fertilization, considering that it accommodates a greater volume of substrate which, in this case, was rich in organic matter and nutrients.
Table 3. Maximum technical efficiency doses (MTED) of controlledrelease fertilizer N-P-K (15-09-12) for the parameters shoot height, root collar diameter, leaf area and shoot dry mass for Inga laurina seedlings in two plastic tubes $\left(110\right.$ and $\left.280 \mathrm{~cm}^{3}\right)$, at 156 days after transplanting.

\begin{tabular}{|c|c|c|}
\hline \multirow{2}{*}{ MTDE } & $110 \mathrm{~cm}^{3}$ & $280 \mathrm{~cm}^{3}$ \\
\hline & - & 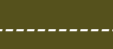 \\
\hline Height & 10.4 & 8.5 \\
\hline Stem diameter & 10.5 & 7.3 \\
\hline Leaf area & 8.5 & 11.0 \\
\hline Shoot dry mass & 10.5 & 10.1 \\
\hline AVERAGE & 10.0 & 9.2 \\
\hline
\end{tabular}

The recommended doses of CRF for seedlings of native species are variable. Based on height and height/ diameter ratio, Gibson et al. (2019) have recommended 
doses of $8 \mathrm{~kg} \mathrm{~m}^{-3}$ to produce Melanoxylon brauna seedlings in $280 \mathrm{~cm}^{3}$ containers. Evaluating seedlings of Mimosa scabrella in growing doses of CRF $\left(0,3,6\right.$ and $\left.9 \mathrm{~kg} \mathrm{~m}^{-3}\right)$, Stüpp et al. (2015) observed superior performance at the $6 \mathrm{~kg} \mathrm{~m}^{-3}$ for the commercial substrate Tecnomax: Navroski et al. (2016) recommended the dose of $5 \mathrm{~kg} \mathrm{~m}^{-3}$ for Cedrela fissilis seedlings. These results suggest that, among other factors, CRF doses can vary accordingly to the nutritional requirement of the different species and the substrate that was used.

The fertilizer applied in the present study had an 8 to 9 months release rate, according to the manufacturer's information. As seedlings were produced in approximately 5 months, the CRF was not entirely released during the nursery phase, which could have led to overestimated values of MTED. For Inga laurina seedlings, in the conditions of the present study, the ideal product should have a release rate of 5 to 6 months, which could possibly reduce the values estimated for the MTED.

The analysis of macronutrients in seedlings tissues showed that, for both containers, the content of nutrients decreased as the CRF doses increased. This result can be explained by the dilution effect, considering that seedlings presented higher growth and biomass at higher CRF doses, the nutrients got diluted in the tissues of seedlings from these treatments (Rossa et al., 2013). The same explanation justifies the higher contents of $\mathrm{P}$ and $\mathrm{K}$ in tissues of seedlings produced in $110 \mathrm{~cm}^{3}$ tubes, when compared to the ones in $280 \mathrm{~cm}^{3}$ that presented higher growth and biomass.

Table 4. Average content of macronutrients in the shoot dry mass $\left(\mathrm{g} \mathrm{kg}^{-1}\right)$ of Inga laurina seedlings produced in two plastic tubes $\left(110\right.$ and $\left.280 \mathrm{~cm}^{3}\right)$ and four CRF doses $\left(0,3,6\right.$ and $\left.12 \mathrm{~kg} \mathrm{~m}^{3}\right)$ at 156 days after transplanting.

\begin{tabular}{ccccccc} 
Tube & Dose & $\mathbf{N}$ & $\mathbf{P}$ & $\mathrm{K}$ & $\mathrm{Ca}$ & $\mathrm{Mg}$ \\
\cline { 2 - 6 }$\left(\mathrm{kg} \mathrm{m}^{-3}\right)$ & & \multicolumn{4}{c}{ Mean content $\left(\mathrm{g} \mathrm{kg}^{-1}\right)$} & \\
& 0 & 23.0 & 3.4 & 7.8 & 21.3 & 0.94 \\
$110 \mathrm{~cm}^{3}$ & 3 & 22.4 & 3.1 & 7.4 & 24.2 & 0.94 \\
& 6 & 19.5 & 2.4 & 7.0 & 17.1 & 0.97 \\
& 12 & 18.5 & 1.6 & 5.7 & 15.6 & 1.13 \\
& 0 & 24.8 & 2.1 & 6.2 & 20.1 & 0.66 \\
& 3 & 24.4 & 2.1 & 6.5 & 18.1 & 0.76 \\
& 6 & 18,2 & 1.6 & 6.0 & 13.6 & 0.87 \\
& 12 & 19.1 & 1.5 & 5.4 & 12.0 & 1.03 \\
\hline $\mathrm{cm}^{3}$ & & & & &
\end{tabular}

The chemical composition of the sewage sludge (Table 1) and of the CRF influenced the contents of Ca and Mg observed in the plants tissues. While the CRF had no Ca and $1 \%$ of Mg in its composition, the biosolids was rich in $\mathrm{Ca}(1.54 \%)$ and poor in $\mathrm{Mg}(0.19 \%)$. This justifies the increasing accumulation of $\mathrm{Mg}$ in the plant tissues that occurred with the increasing doses of CRF. Regarding $\mathrm{Ca}$, the content in seedlings tissues decreased with the increasing doses of CRF, considering that there was no addition of this nutrient via fertilization and the dilution of it in the biomass of seedlings from treatments with higher CRF doses.

No signs of nutrients deficiency were observed in seedlings of any treatment. Considering the data from quality, growth and nutritional parameters, it was possible to produce adequate seedlings of Inga laurina without fertilization. This result can be justified by the substrate, considering that sewage sludge is rich in nutrients and organic matter. Other studies verified the possibility to produce seedlings of native species with sewage sludge as substrate and without fertilization, like Siqueira et al. (2018) for Lafoensia glyptocarpa and Cabreira et al. (2017) for Lafoensia pacari, Peltophorum dubium and Ceiba speciosa. Despite that higher doses of fertilizers resulted in higher and faster growth, it is worth noting that not necessarily these gains would compensate the increase in expenses with fertilizer.

\subsection{Outplanting phase}

Survival rate of Inga laurina seedlings at 5 months after outplanting varied from 90 to $100 \%$ between the treatments (Table 5), which was favored by the application of hydrogel and by the precipitation observed in the first four months after planting (December to March). Lower survival rates, that ranged between 75 to $100 \%$, were observed at 12 months after outplanting, which can be attributed to the reduction of precipitation between June and October, combined with the low water holding capacity of the planting site soil.

The survival rate was higher in $280 \mathrm{~cm}^{3}$ tubes, showing that seedlings produced in larger containers were more tolerant to the adverse conditions of the planting site. Leles at al. (2006) observed similar results for Cedrela fissilis, where seedlings produced in $280 \mathrm{~cm}^{3}$ containers had greater survival rate at 30 days after outplanting, whilst no difference was reported for pioneer species Schinus terebinthifolia and Chorisia speciosa produced in 115 and $280 \mathrm{~cm}^{3}$ tubes. It is worth noting that climate conditions of the site where Leles at al. (2006) conducted their study were not as adverse as the ones observed in the present experiment. Besides, the authors assessed the survival rate only in the first month after outplanting, whereas in the present study it was assessed at 5 and 12 months after outplanting. 
Table 5. Average values of height and Dickson quality index (DQI) at planting and average values of height (H), diameter (DGL) and survival rate (S) at 5 and 12 months after planting of Inga laurina seedlings produced in two plastic tubes $\left(110\right.$ and $\left.280 \mathrm{~cm}^{3}\right)$ and four CRF doses $\left(0,3,6\right.$ and $\left.12 \mathrm{~kg} \mathrm{~m}^{-3}\right)$, in a reforestation area in São Francisco do Itabapoana - RJ.

\begin{tabular}{|c|c|c|c|c|c|c|c|c|}
\hline \multirow{2}{*}{ Tube volume } & \multicolumn{3}{|c|}{-Planting- } & \multicolumn{2}{|c|}{------ 5 months ------ } & \multicolumn{3}{|c|}{------------- 12 months ------------ } \\
\hline & Dose & $\mathrm{H}(\mathrm{cm})$ & DQI & S (\%) & $\mathbf{H}(\mathbf{c m})$ & S (\%) & $\mathbf{H}(\mathbf{c m})$ & DGL (mm) \\
\hline \multirow{5}{*}{$110 \mathrm{~cm}^{3}$} & 0 & 20.2 & 2.15 & 90 & 28.9 & 75 & 44.3 & 12.1 \\
\hline & 3 & 26.0 & 2.45 & 90 & 36.0 & 85 & 48.3 & 13.2 \\
\hline & 6 & 28.5 & 2.62 & 100 & 38.4 & 95 & 52.9 & 14.5 \\
\hline & 12 & 32.9 & 2.68 & 100 & 41.6 & 100 & 50.7 & 12.8 \\
\hline & Average & $26.9^{*}$ & $2.47^{*}$ & 95 & $36.2^{\star}$ & 88.8 & $49.1^{\mathrm{ns}}$ & $13.2^{*}$ \\
\hline \multirow{5}{*}{$280 \mathrm{~cm}^{3}$} & 0 & 28.9 & 2.15 & 90 & 38.6 & 85 & 50.5 & 14.3 \\
\hline & 3 & 36.4 & 2.50 & 100 & 44.5 & 95 & 55.2 & 17.4 \\
\hline & 6 & 37.9 & 2.74 & 100 & 46.0 & 100 & 56.0 & 16.1 \\
\hline & 12 & 40.8 & 3.01 & 95 & 48.0 & 90 & 57.8 & 17.5 \\
\hline & Average & $36.0^{*}$ & $2.60^{*}$ & 96.3 & $44.3^{*}$ & 92.5 & $54.9^{\mathrm{ns}}$ & $16.3^{*}$ \\
\hline
\end{tabular}

* significant between containers at $5 \%$ level according to the t-test ( $\mathrm{p}>0.95) ;{ }^{\text {ns }}$ non-significant.

According to Bellotto et al. (2009), in a forest restoration planting, a mortality rate above $10 \%$ demands immediate corrective action. In this context, at 12 months after planting, seedlings presented acceptable mortality rate when received doses equal or greater than $6 \mathrm{~kg} \mathrm{~m}^{-3}$ of CRF in the $110 \mathrm{~cm}^{3}$ tube and equal or greater than $3 \mathrm{~kg} \mathrm{~m}^{-3}$ for the $280 \mathrm{~cm}^{3}$ tube. Seedlings without fertilization showed higher mortality rates, which can be explained by their inferior quality and growth in most of the parameters evaluated in the nursery experiment. The need of fertilization to produce high quality I. laurina seedlings can be attested, even when using sewage sludge as substrate, a material that is rich in organic matter and in which the nutrients are gradually released (Abreu et al., 2019).

Seedlings produced in $280 \mathrm{~cm}^{3}$ tubes (Table 5) were rated as superior quality through Dickson quality index (DQI), calculated before planting. Independent of the container size, higher CRF doses had direct effect on increasing the DQI of seedlings, stressing out the beneficial effect of this fertilization method. The DQI varies greatly between species and few literature data is available for Atlantic Forest species. Two other studies were found evaluating this parameter for $I$. laurina, both using $115 \mathrm{~cm}^{3}$ plastic tubes, Góes et al. (2015) observed values between 0.37 and 0.97 , among different treatments, and Jesus et al. (2016) verified values of from 0.07 to 0.13 , both studies showed values of DQI bellow the ones of the present experiment. Considering a survival rate of at least
$90 \%$ at 12 months after outplanting, in the conditions of the present study, it was observed that seedlings with DQI equal or higher than 2.62 and 2.50 were suitable to outplanting, respectively, in $110 \mathrm{~cm}^{3}$ and $280 \mathrm{~cm}^{3}$ tubes.

The seedlings produced in $280 \mathrm{~cm}^{3}$ tubes showed significantly higher growth in height, at 5 months after outplanting, and in diameter at 12 months, when compared to seedlings of 110 $\mathrm{cm}^{3}$ tubes. At 12 months after outplanting, no difference was observed for height, considering that seedlings in the $110 \mathrm{~cm}^{3}$ tubes had superior average increment, suggesting that the growth of plants from both recipients would equal further ahead. Similar results were observed for Cabralea canjerana by Gasparin et al. (2014), which underlines that a year after planting, there was no significant difference for growth in height of seedlings produced in 100 and $280 \mathrm{~cm}^{3}$ tubes. Other authors reported similar trend, like Keller et al. (2009) for Inga marginata, Jacaranda puberula and Zeyheria tuberculosa, and Abreu et al. (2015) for Enterolobium contortisiliauum produced in 280 and $180 \mathrm{~cm}^{3}$ tubes. It is possible to suppose that, in the long term, plants growth at restoration sites is not influenced by the container in which the seedlings were produced.

\section{CONCLUSIONS}

In the nursery stage, higher doses of controlled-release fertilizer (CRF) resulted in Inga laurina seedlings of superior 
quality, higher growth and produced in shorter time for both 110 and $280 \mathrm{~cm}^{3}$ plastic tubes. Seedlings produced in $280 \mathrm{~cm}^{3}$ tubes showed higher growth and quality than those produced in $110 \mathrm{~cm}^{3}$ tubes. The most efficient doses of CRF were 10.0 and $9.2 \mathrm{~kg} \mathrm{~m}^{-3}$, respectively for 110 and $280 \mathrm{~cm}^{3}$ tubes, considering the CRF release time and the substrate used in the study. To produce seedlings of Inga laurina, considering only the nursery results, it is recommend using the $280 \mathrm{~cm}^{3}$ tube and CRF doses of $9.2 \mathrm{~kg} \mathrm{~m}^{-3}$.

Evaluating data collected after outplanting, the seedlings produced in $280 \mathrm{~cm}^{3}$ tubes showed higher survival rate and initial growth than those produced in $110 \mathrm{~cm}^{3}$. Considering the survival and growth of Inga laurina at 12 months after planting, seedlings presented acceptable performance when received doses equal or greater than $6 \mathrm{~kg} \mathrm{~m}^{-3}$ of CRF in the $110 \mathrm{~cm}^{3}$ tube and equal or greater than $3 \mathrm{~kg} \mathrm{~m}^{-3}$ for the $280 \mathrm{~cm}^{3}$ tube.

\section{SUBMISSION STATUS}

Received: 09 Mar. 2019

Accepted: 13 Oct. 2020

Associate editor: José Henrique Tertulino Rocha (ib

\section{CORRESPONDENCE TO}

\section{Jorge Makhlouta Alonso}

Universidade Federal Rural do Rio de Janeiro, Km 07, Zona Rural, BR-465, CEP 23890-000, Seropédica, RJ, Brasil

e-mail: j_makh@hotmail.com

\section{REFERENCES}

Abreu AHM, Alonso JM, Melo LA, Leles PSS, Santos GR. Caracterização de biossólido e potencial de uso na produção de mudas de Schinus terebinthifolia Raddi. Revista Engenharia Ambiental e Sanitária 2019; 24 (3): 591-599.

Abreu AHM, Leles PSS, Melo LA, Ferreira DHAA, Monteiro FAS. Produção de mudas e crescimento inicial em campo de Enterolobium contortisiliquum produzidas em diferentes recipientes. Floresta 2015; 45 (1): 141-150.

Bamberg R, Behling A, Perrando ER, Sanquetta CR, Nakajima, NY, Schreiner T et al. Relação entre nutrição e tempo de permanência de mudas de Bauhinia forficata em casa de vegetação. Silva Lusitana 2013; 21 (1): 87-101.

Bellotto A, Viani RAG, Nave AG, Gandolfi S, Rodrigues RR. Monitoramento das áreas restauradas como ferramenta para avaliação da efetividade das ações de restauração e para redefinição metodológica. In: Rodrigues RR, Brancalion PHS, Isernhagen I. Pacto para a restauração da Mata Atlântica: referencial dos conceitos e ações de restauração florestal. São Paulo: LERF/ESALQ; 2009.

Cabreira GV, Leles PSS, Alonso JM, Abreu AHM, Lopes NF, Santos GR. Biossólido como componente de substrato para produção de mudas florestais. Floresta 2017; 47 (2): 165-176.
Ferraz AV, Engel VL. Efeito do tamanho de tubetes na qualidade de mudas de jatobá (Hymenaea courbaril L. Var. stilbocarpa (Hayne) Lee et Lang.), ipê-amarelo (Tabebuia chrysotricha (Mart. ex DC.) Sandl.) e guarucaia (Parapiptadenia rigida (Benth.) Brenan). Revista Árvore 2011; 35 (3): 413-423.

Freitas TAS, Barroso DG, Carneiro JGA, Penchel RM, Figueiredo FAMMA. Mudas de eucalipto produzidas a partir de miniestacas em diferentes recipientes e substratos. Revista Árvore 2006; 30 (4): 519-528.

Gasparin E, Araujo MM, Saldanha CW, Tolfo CV. Controlled release fertilizer and container volumes in the production of Parapiptadenia rígida (Benth.) Brenan seedlings. Acta Scientiarum Agronomy 2015; 37 (4): 473:481.

Gasparin E, Avila AL, Araujo MM, Cargnelutti Filho A, Dorneles DU, Foltz DRB. Influência do substrato e do volume de recipiente na qualidade das mudas de Cabralea canjerana (Vell.) Mart. Em viveiro e no campo. Ciência Florestal 2014; 24 (3): 553-563.

Gibson EL, Gonçalves EO, Santos AR, Araújo EF, Caldeira MVW. Controlled-Release Fertilizer on Growth of Melanoxylon brauna Shott Seedlings. Floresta e Ambiente 2019; 26, e20180418.

Góes GS, Gross E, Rocha EB, Mielke MS. Efeitos da inoculação com bactérias diazotróficas e da adubação nitrogenada no crescimento e na qualidade de mudas de Inga laurina (SW.) Willd. (Fabaceae). Revista Árvore 2015; 39 (6): 1031-1038.

Irfan SA, Razali R, Kushaari K, Mansor N, Azeem B, Versypt ANF. A review of mathematical modeling and simulation of controlledrelease fertilizers. Journal of Controlled Release 2018; 271 (10): 45-54.

Jesus MFC, Souza Júnior JO, Góes GS, Rocha EB, Mielke MS. Crescimento e qualidade de mudas de Inga laurina em função do substrato e adubação complementar. Pesquisa Florestal Brasileira 2016; 36 (86): 153-159.

Keller L, Leles PSS, Oliveira Neto SN, Coutinho RP, Nascimento DF. Sistema de blocos prensados na produção de mudas de espécies arbóreas. Revista Árvore 2009; 33 (2): 305-314.

Leles PSS, Lisboa AC, Oliveira Neto SN, Grugiki MA, Ferreira MA. Qualidade de mudas de quatro espécies florestais produzidas em diferentes tubetes. Floresta e Ambiente 2006; 13 (1): 69-78.

Martins ACF, Schiavini I, Araújo GM, Lopes SF. Capacidade adaptativa de espécies do cerrado utilizadas em áreas de recuperação ambiental. Revista Árvore 2015; 36 (3): 543-550.

Melo LA, Abreu AHM, Leles PSS, Oliveira RR, Silva DT. Qualidade e crescimento inicial de mudas de Mimosa caesalpiifolia Benth. produzidas em diferentes volumes e recipientes. Ciência Florestal 2018; 28 (1): 47:55.

Moraes Neto SP, Gonçalves JLM, Rodrigues CJ, Geres, WLA, Ducatti F, Aguirre Jr JH. Produção de mudas de espécies arbóreas nativas com combinações de adubos de liberação controlada e prontamente solúveis. Revista Árvore 2003; 27 (6): 779-789.

Navroski MC, Tonett EL, Mazzo MV, Frigotto T, Pereira MO, Galvani LV. Procedência e adubação no crescimento inicial de mudas de cedro. Pesquisa Florestal Brasileira 2016; 36 (85): 17-24.

Pias CHO, Berghetti J, Somavilla L, Cantarelli EB. Qualidade de mudas de cedro em função da utilização de fertilizantes e recipientes de diferentes tamanhos. Revista Agroambiente 2015; 9 (2): 208-213.

Rossa UB, Angelo AC, Nogueira AC, Westphalen DJ, Bassaco MVM, Milani JEF et al. Fertilizante de liberação lenta no desenvolvimento 
de mudas de Schinus terebinthifolius e Sesbania commersoniana. Floresta 2013; 43 (1): 93-104.

Scheer MB, Carneiro C, Santos KG. Crescimento de mudas de Prunus brasiliensis (Cham. \& Schltdl.) D. Dietr. em substratos à base de lodo de esgoto compostado e fertilizante mineral. Ciência Florestal 2012a; 22 (4): 739-747.

Scheer MB, Carneiro C, Bressan OA, Santos KG. Composto de lodo de esgoto para a produção de mudas de Anadenanthera colubrina (Vell.) Brenan. Cerne 2012b; 18 (4): 613-621.
Siqueira DP, Carvalho GCMW, Barroso DG, Marciano CR. Lodo de esgoto tratado na composição de substrato para produção de mudas de Lafoensia glyptocarpa. Floresta 2018; 48 (2): 277-284.

Souza VC, Lorenzi H. Botânica Sistemática: Guia ilustrado para identificação das famílias de angiospermas da flora brasileira, baseado em APGII. 1st ed. Nova Odessa: Instituto Plantarum; 2005.

Stüpp AM, Navroski MC, Felippe D, Kniess DDC, Amancio JC, Silva MA et al. Crescimento de mudas de Mimosa scabrella Benth em função de diferentes tamanhos de recipientes e doses de fertilizante. Ecologia e Nutrição Florestal 2015; 3 (2): 40-47. 